Journal of Applied Pharmaceutical Science Vol. 5 (08), pp. 114-125, August, 2015

Available online at http://www.japsonline.com

DOI: $10.7324 /$ JAPS.2015.50818

ISSN 2231-3354 (cc) BY-NC-SA

\title{
Antibacterial and anti-hyperlipidemic activities of the brown alga Hormophysa cuneiformis from Ad Dammam Seashore
}

\author{
Neveen Abdel-Raouf ${ }^{1}$, Nouf Mohammad Al-Enazi ${ }^{2}$, Ibraheem B.M. Ibraheem ${ }^{1 *}$, Reem Mohammad Al-Harbie ${ }^{3}$ \\ ${ }^{1}$ Botany and Microbiology Department, Faculty of Science, Beni-Suef University, Egypt. \\ ${ }^{2}$ Biology Department, Faculty of Science and Humanities, Salman Bin Abdulaziz University, Alkharj, Saudi Arabia \\ ${ }^{3}$ Scientific Department, Faculty of Education, Dammam University, Hafr Al-Batin Saudi Arabia
}

\section{ARTICLE INFO \\ Article history: \\ Received on: 06/10/2014 \\ Revised on: 14/12/2014 \\ Accepted on: 08/01/2015 \\ Available online: 28/08/2015}

\section{Key words:}

Antibacterial activity, antioxidant activity,

Hormophysa cuneiformis

\begin{abstract}
A laboratory experiment was conducted to test antibacterial activity of ethanol extract of the brown alga Hormophysa cuneiformis against three types of Gram-positive and three of Gram-negative bacteria, where extracts of this alga proved efficient activity against these pathogenic bacteria species ranged between medium and high suppression action. Also, we evaluated the effects of $H$. cuneiformis ethanolic extract and its major constituents on the serum lipid and protein levels of hyperlipidemic rats induced by the administration of a highcholesterol diet. Results revealed the efficiency of H. cuneiformis extract in the decreasing the levels of the total cholesterol (TC), triglycerides (TG), low-density lipoproteins (LDL-C), blood urea nitrogen (BUN) and creatinine caused by alcohol. On the other hand, the treatment by alga extract exhibit significant increase in the high-density lipoproteins (HDL-C) (beneficial), total protein, albumin and globulins. The algal treatments also masking the lethal effects caused by harmful alcohol from raising the rate of enzymes ALT, AST, which returned to normal state in the groups treated by alga extract. Also, the histopathological examination of the ethanol treated groups of rate revealed degeneration and necrotic changes as compared to the administrated rate groups with alga extract which showed marked amelioration of the severity of these changes.
\end{abstract}

\section{INTRODUCTION}

The necessity of compounds with antioxidant activity is increasing as it is realized that the formation of reactive oxygen species (ROS) and reactive nitrogen species (RNS) have been linked in the pathogenesis of several human diseases such as atherosclerosis, diabetes mellitus, chronic inflammation, neurodegenerative disorders and certain types of cancer (Collier et al., 1990, Boynes 1991). Oxygen free radicals disintegrate DNA, destroy cell membranes, and create havoc among cell's basic enzymatic metabolic processes (Kerr et al., 1991). Among the major causative factors in induction of many chronic and degenerative diseases including atherosclerosis, diabetes mellitus, cancer, Parkinson's disease and immune dysfunction and is involved in aging (Halliwell, 2000; Metodiewa and Koska, 2000; Young and Woodside, 2001). The formation of cancer cell in human body can be directly induced by free radicals.

* Corresponding Author

Ibraheem B.M. Ibraheem, Botany and Microbiology Department,

Faculty of Science, Beni-Suef University, Egypt.

E-mail: ibraheemborie@science.bsu.edu.eg
Furthermore, ionizing radiation, which causes free radicals, is well documented as a carcinogen. Radicals which have one or more unpaired electrons are produced in normal or pathological cell metabolism. Free Reactive oxygen species (ROS) react easily with free radicals to become radicals themselves. ROS are various forms of activated oxygen, which include free radicals such as superoxide anion radicals $\left(\mathrm{O}_{2}\right)$ and hydroxyl radicals $(\mathrm{OH})$, as well as non-free radical species $\left(\mathrm{H}_{2} \mathrm{O}_{2}\right)$ and the singled oxygen $\left(\mathrm{O}_{2}\right)$. The antioxidant activity of these compounds are mainly attributed to scavenging activity against superoxide and hydroxyl radicals, chelating ability, quenching singlet and triplet oxygen, and reducing power (Ruberto et al., 2001, Athukorala et al., 2006). It is important to develop, identify and utilize new source of safe and effective antioxidants of natural origin (Li et al., 2007, Qi et al., 2005). There are several synthetic antioxidants such as butylated hydroxyanisole (BHA), butylated hydroxytoluene (BHT), Propylgallate (PG) and butylated hydroxyquinone (TBHQ) are commercially available and currently used. However, the use of these synthetic antioxidants for food or medicine components has been restricted by the toxicity and safety that can lead to the problems of the potential health in human. 
Due to the reasons, many researchers have tried to find the more effective oxidation inhibitors that may be used as antioxidants for food or medicine compositions without the side effects for the past several years. So many researchers have paid attention to many kinds of natural antioxidants that can be used without toxicity in human (Capasso 2012). Marine macroalgae are rich sources of several compounds with biological effects including antioxidant activities (Ibraheem et al., 2012).

Marine algae have been use as a novel food with potential nutritional benefits and in industry and medicine for various purposes (Santoso et al., 2004). Recently, aquatic habitats have increasing been shown to provide a rich source of natural bioactive compounds with hypocholesterolemia, antinflammatory, antiviral, antineoplastic, antimicrobial and hypertensive properties. According to their chemical structure, most of isolated compounds belong to sulfated polysaccharides, phenolics, terpenoids, lactons, sterol and fatty acids (Qi et al., 2005, McDermid and Stuercke, 2003, Duan et al., 2006).

On the other hand, the antioxidant activity is one of the most important active in marine bioactive substances and lots of algal and algae-derived compounds exhibited potent antioxidant such as carotenoids, phenolics, terpenoids and sulphated polysaccharides. The antioxidant activity of these compounds are mainly attributed to scavenging activity against superoxide and hydroxyl radicals, chelating ability, quenching singlet and triplet oxygen and reducing power (Ruberto et al., 2001, Athukorala et al., 2006).

In a continuation of the search for algae-derived antihypercholesterolemic and hypolipidemic agents, we evaluated the potential of the brown alga Hypophysea cuneiformis as antihyperlipidemic agaents in rats.

\section{MATERIAL AND METHODS}

\section{Antibacterial activity of the studied algae \\ Extraction of selected algal species}

Twenty five grams of the alga dry weight were socked in $250 \mathrm{ml}$ of ethanol for 24 hours. The waited grams were homogenized in a blender with solvent at room temperature, then filtration and concentration under reduced pressure by using rotary evaporator.

\section{Test microorganisms}

Three gram-positive bacteria Staphylococcus aureus (ATCC29213), Methicillin-resistant Staphylococcus aureus (MRSA) ATCC 12498 and Enterococcus faecalis ATCC 29212 and three gram-negative bacteria Escherichia coli (ATCC25922), Pseudomonas aeruginosa ATCC 27853 and Klebsiella pneumoniae ATCC27738 were used for this test. The bacteria strains were obtained from the Riyadh military Hospital. The bacterial stock cultures were maintained at $4^{\circ} \mathrm{C}$.

\section{Evaluation of antimicrobial Activity}

The bacterial strains were maintained on suitable medium at $4{ }^{\circ} \mathrm{C}$ and subculture on Mueller Hinton Broth at $37{ }^{\circ} \mathrm{C}$ for $18 \mathrm{~h}$ before testing. Antibacterial activity was measured using a well diffusion method according to (Prabhu et al., 2010).

\section{Medium used for bacterial maintenance.}

Nutrient agar medium was used to maintain the tested organisms. Bacteria were inoculated on solid medium for 24 hours at $37{ }^{\circ} \mathrm{C}$ using slope culture. Cultures were kept in refrigerator at 4 ${ }^{\circ} \mathrm{C}$ and they were sub-cultured every month on the same medium.

\section{Biological analysis \\ Experimental animal}

The experiment was conducted on 45 male western albino rats weighting 150-180 gm were obtained from Animal House Care Center, College of Pharmacy, King Saud University, Riyadh, Saudi Arabia.

The animals were housed in stainless-steel cages under strict hygienic conditions and maintained at standard laboratory conditions of temperature, relative humidity and light/dark cycle as well as a standard pelleted diet. The animals were acclimatized to laboratory conditions for 7 days prior to the commencement of the experiment .

\section{Experimental design}

The animals were divided into 6 groups, each group contain 6 rats. Group 1 as a control and the other groups (G2 G6) were receiving the treatment according to the protocol of the research.The following protocol illustrate the number of the group and the treatment administered (see Figure 1).

Group 1: Animals fed on normal pallet diet and receive ordinary water as control.

Group II: Animals were given $1.5 \mathrm{ml}$ of $10 \%$ ethanol daily.

Group III: Animals were given $1.5 \mathrm{ml}$ of $25 \%$ ethanol daily.

Group IV: Animals received both ethanol $1.5 \mathrm{ml}$ of $10 \%$ daily and $250 \mathrm{mg} / \mathrm{kg} \mathrm{b}$. wt./day) of $H$. cuneiformis ethanolic extract.

Group V: Animals received both ethanol $1.5 \mathrm{ml}$ of $25 \%$ daily and $250 \mathrm{mg} / \mathrm{kg} \mathrm{b}$. wt./day) of $H$. cuneiformis ethanolic extract.

Group VI: Animals received $250 \mathrm{mg} / \mathrm{kg} \mathrm{b}$. wt./day) of H. cuneiformis ethanolic extract.

All the rats of various experimental groups received treatment for 30 days. The treatment was given once daily by the oral route. Blood samples were collected from 3 rats in each group before the beginning, mid and end of experiment for detection of biochemical changes. 


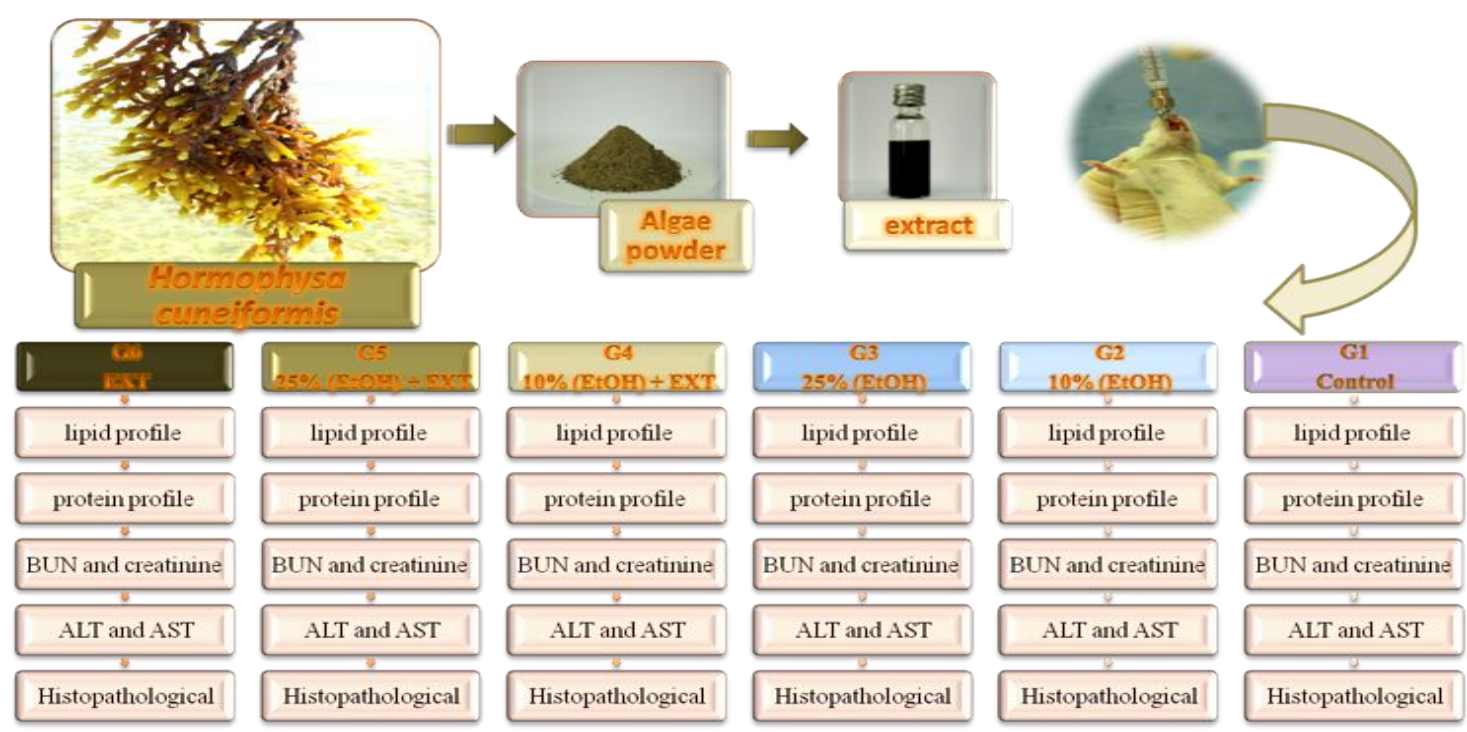

Fig. 1: The protocol diagram illustrates the work plan of the biological study using the green alga H. cuneiformis.

\section{Biochemical analyses \\ Blood Lipid Profiles}

Total cholesterol (TC), triglycerides (TG), high-density lipoprotein cholesterol (HDL-C), low-density lipoprotein (LDL-C) cholesterol, and induced hepatic damage by measuring levels of Blood Urea Nitrogen BUN, Creatinine, Total proteins, albumin and Globulin and diagnostic marker enzymes such as Aspartate aminotransaminase (AST) and Alanine aminotransaminase (ALT). Blood samples were collected from the orbital sinus by use of glass capillary tube or from the toil vein by use of catheter 24 GA1.00 IN to prevent movement that will result in laceration of a blood vessel or other organ. Homeostasis was achieved by using gauze and direct pressure. For different hematological and serological studies, blood collected in a plain vacuum tube and in citrated buffered tube. Euthanasia was conducted in rats with aid of in helant anesthetic (Sevorane). The procedures of anesthesia were carried out according to method of Howard and Hughes (Howard and Hughes, 1981), while those for euthanasia were carried according to method of Lucke (1979). Sample from liver were collected from the animals and preserved in $10 \%$ formalin for histopathological studies.

\section{Estimation of Cholesterol (ENSURE Kit) (TC)}

To $1 \mathrm{ml}$ of enzyme reagent and $10 \mu \mathrm{l}$ of plasma was mixed well and kept at $37^{\circ} \mathrm{C}$ for 5 minutes at room temperature and the absorbance was measured by using spectrophotometer at $505 \mathrm{~nm}$. The activity was calculated by using the formula:

Cholesterol conc. $\mathrm{mg} / \mathrm{dl}=$ Absorbance of Test/ Absorbance of Standard x Conc. of Std (200).

\section{Estimation of Triglycerides (TG)}

Ten $\mu$ of plasma sample mixed with $1000 \mu l$ of enzyme reagent and incubated for 5 minutes at $37^{\circ} \mathrm{C}$. At the same time blank and standard solution was prepared. The absorbance of sample against reagent blank was read at $540 \mathrm{~nm}$. The activity was calculated by using the formula:
Triglycerides conc. $(\mathrm{mg} / \mathrm{dl})=$ absorbance of sample/absorbance of standard $\times 200$

\section{HDL-Cholesterol}

To $200 \mu \mathrm{l}$ of plasma sample $300 \mu \mathrm{l}$ of HDL ppt reagent was added and mixed well and kept at room temperature for 10 minutes then centrifuged at $3000 \mathrm{rpm}$ for 10 minutes. Then the pellet was discarded and $1 \mathrm{ml}$ of enzyme reagent was added to 100 $\mu l$ of supernatant, then incubated for 5 minutes at $37^{\circ} \mathrm{C}$ and the absorbance was read at $505 \mathrm{~nm}$. The activity was calculated by using the formula:

HDL Cholesterol conc.mg/dl: Abs of Test/Abs of standard x Conc of Std (50).

\section{Atherogenic Index (AI)}

It was calculated by using the following formula:

Atherogenic index $=$ Total cholesterol $/$ HDL-cholesterol

\section{LDL-Cholesterol}

The reason for choosing LDL cholesterol as a target for lipid profile is that it represents the fraction of cholesterol, which is most deleterious and has been mostly directly correlated with clinical studies. The LDL was calculated by using the formula: $\mathrm{LDL}=($ Total cholesterol $)-($ HDL Cholesterol $)-($ Triglyceride $/ 5)$ LDL cholesterol levels were expressed as $\mathrm{mg} / \mathrm{dl}$ plasma.

\section{Risk factor}

It was determined by using the formula: Risk factor $=\mathrm{LDL} / \mathrm{HDL}$

Plasma Enzymes Profile (AST and ALT) Assay of aspartate transaminase (AGAPPE Diagnostics Kit)

To $1000 \mu \mathrm{l}$ of working reagent and $100 \mu \mathrm{l}$ of sample was added, mixed and incubate for 1 minute at $37^{\circ} \mathrm{C}$ and the absorbance was measured. The activity was calculated by using the formula:

ALT activity in $(\mathrm{U} / \mathrm{L})=(\Delta \mathrm{OD} / \mathrm{min}) \times 1745$ 
Assay of alanine transaminase (AGAPPE Diagnostics Kit)

To $1000 \mu \mathrm{l}$ of working reagent and $100 \mu \mathrm{l}$ of plasma was added, mixed and incubate for 1 minute at $37^{\circ} \mathrm{C}$ and the absorbance was measured at $340 \mathrm{~nm}$. By using the following formula the AST activity was measured.

$$
\text { AST activity }(\mathrm{U} / \mathrm{L})=(\Delta \mathrm{OD} / \mathrm{min}) \times 1745
$$

\section{ALT: AST Ratio.}

It was determined using the following formula.

$$
\text { ALT: AST Ratio }=\text { ALT/AST }
$$

\section{Estimation of plasma and organs protein profile Total protein (Autozyme kit)}

To $0.01 \mathrm{ml}$ of plasma/tissues extract and $1 \mathrm{ml}$ of working solution was added and incubated the assay mixture for 5 minutes at $37^{\circ} \mathrm{C}$. After completion of incubation period the absorbance was measured at $546 \mathrm{~nm}$. The activity was calculated by using the formula:

Total protein in $\mathrm{gm} \%=$ Absorbance of sample/Absorbance of standard $\mathrm{x} 5$

\section{Total albumin (Autozyme Kit)}

To $0.01 \mathrm{ml}$ of plasma and $1 \mathrm{ml}$ of working solution was added and incubated the assay mixture for 1 minute at $37^{\circ} \mathrm{C}$. After completion of incubation period the absorbance was measured at $600 \mathrm{~nm}$. The activity was calculated by using the formula:

Total albumin in $\mathrm{gm} \%=$ Absorbance of sample/Absorbance of standard $\mathrm{x} 5$

\section{Estimation of globulin (Autozyme Kit)}

To $0.01 \mathrm{ml}$ of plasma and $1 \mathrm{ml}$ of working solution was added and incubated the assay mixture for 1 minute at $37^{\circ} \mathrm{C}$. After completion of incubation period the absorbance was measured at $600 \mathrm{~nm}$. The activity was calculated by using the formula:

Total albumin in $\mathrm{gm} \%=$ absorbance of sample/absorbance of standard $\mathrm{x} 3$.

\section{Histopathological studies}

The histopathological studies were carried out to support the above parameters. At the end of experiment 2 rats from each group were sacrificed and specimens from liver were collected for histopathological studies were recorded.

After the animals were sacrificed, small parts of the liver were fixed in $10 \%$ formalin, washed in tap water, dehydrated, cleared and embedded in paraffin. Sections were cut and stained with hematoxylin and eosin for assessment the cases. To be examined under light microscopy (see Fig. 2).

\section{Statistical analysis}

All results are presented as the mean \pm SD. Statistical analysis was carried out by using one-way ANOVA followed by Dunnett's multiple comparison tests using Graph pad PRISM software version. Statistical significance was considered at $p<0.05, p<0.01$ and $p<0.001$.

\section{Result and discussion Antibacterial screening of the studied algae}

Extracts of the brown alga $H$. cuneiformis was tested against some pathogenic bacteria. The results of primary screening test are summarized in Table 1. In this study, six pathogenic bacteria were considered, namely, S. aureus, MRSA, E. faecalis, E. coli, K. pneumonia and P. aeruginosa. The crude extract of the studied marine alga exhibited different antibacterial activities and inhibited all tested bacteria. The maximum biological activities were observed against $P$. aeruginosa. Where the inhibition zone reached $40 \mathrm{~mm}$. Alga extract also responsible for the observed effects against the other pathogenic bacteria.

These results indicate that the extracts contained different antibacterial substances and reflect the variety of secondary metabolites (Patterson et al., 1994). The compounds responsible for the antimicrobial activity assume that the active compounds could be at least partly, lipophilic halogenated compounds. Halogen-containing terpenoids, acetylens and phenols have been identified in several algal species as biologically active compounds (Vairappan et al., 2001). Besides halogenated compounds, fatty acids have been identified as antimicrobial substances in algae (Rosell and Srivastava 1987). Many compounds of marine algae show anti-bacterial activities such as polysaccharide (Laurienzo 2010), lyengaroside(Ali et al., 2002), polyhydroxy lated fucophlorethol (Sandsdalen et al., 2003), bromophenols (Oh et al., 2008), guaianesesquiterpene (Chakraborty and Lipton 2010), lactone malyngolide (Cardelina et al., 1979) cycloeudesmol (Sims et al., 1975), polyphenolic compound (Devi 2008), halogenated compound (Vairappan, 2003) and quinone metabolite (Horie et al., 2008).

Antibacterial activities of compounds derived from algae have also been extensively studied by several other researchers (Dmirel et al., 2009, Rajasulochana et al., 2009, Seenivasan et al., 2010).

\section{Pharmacological Studies}

Effect of $\boldsymbol{H}$. cuneiformis extract on the lipid profile of ethanoladministrated rats,

Effect of H. cuneiformis extract on the TC

When reviewing the results of the impact of injection with the brown alga $H$. cuneiformis extract on administrated rats (Table 2), we conclude that, the injecting alcohol (10 and $25 \%)$ causes a significant increase in the TC levels for rats, while the injection with the brown alga $H$. cuneiformis extract significantly reduce this levels which appeared anti-hyperlipidemic properties. The results also showed that, the second group which treated with $10 \%$ ethanol showed a significant increase in the TC level $(\mathrm{P}<0.01)$ reached 18.59 and $30.36 \%$ after 15,30 days, respectively. Also, the $3^{\text {rd }}$ group which treated with $25 \%$ ethanol showed significant increasing in the level of TC $(\mathrm{P}<0.01)$ reached 
25.54 and $34.60 \%$ after 15,30 days of injection, respectively. On the other hand, the fourth and fifth groups which treated by 10 or $25 \%$ ethanol together with the H. cuneiformis extract showed insignificant increases in TC levels reached 5.23, 3.08\% for the fourth member after 15 and 30 days of injection, respectively and $1.37 \%$ for members of fifth group after 15 days of injection. On the contrary, there is a decreasing in the TC levels for the members of this group after 30 days of injection reached $2.27 \%$. It is also surprising that the injection by $H$. cuneiformis extract of those groups which previously injected by alcohol has led to a decrease in the rate of TG levels reached 13.36, 27.28\% in the fourth group and $24.17,36.87 \%$ in the fifth group after 15 and 30 days, respectively. Additionally, the injection with $H$. cuneiformis extract for the members of the sixth group will effective in reducing the rate of TC, where TC level decreased by $4.71,9.71 \%$ after 15,30 days of the injection, respectively.

\section{Effect of H. cuneiformis extract on the TG}

Regarding results contained in the Table.2, and comparing the results of the treated groups (2-6) with the control group, we found different behaviors in triglyceride levels. Where the members of the second group reflect significant $(\mathrm{P}<0.05)$ increasing in TG levels reached $8.91 \%$ after 15 days and recorded a significant $(\mathrm{P}<0.01)$ increasing reached $59.07 \%$ after 30 days of injections. While the treatment of the third group with $25 \%$ ethanol leads to the significant (at $\mathrm{P}<0.01$ ) increasing in TG levels reached 21.72 and $70.79 \%$ after 15,30 days of treatment, respectively. On the other hand, the fourth and fifth groups exhibit insignificant increasing in TG levels reached 6.71 and $8.83 \%$ for members of the fourth group and 3.93, 7.31\% for the member of the fifth group after 15, 30 days of treatment, respectively. Comparing the increase in the levels of triglycerides in the rats of treated groups (2-5), we found the treatment with $H$. cuneiformis extract addition to being injected previously with alcohol has led to a decrease in the alcohol action (elevation of TG) by 2.74 and $50.24 \%$ for members of fourth group and $17.79,63.48 \%$ for the member of the fifth group after 15, 30 days of injection, respectively. Finally, the results of the sixth group treated with $H$. cuneiformis extract showed insignificant decrease in the level of triglycerides reached 2.17 and $2.52 \%$ after 15 and 30 days of the injection, respectively. Most cholesterol in the body is present as essential components of the cell membrane, while the remainder is in transit though the blood or functions as a starting material for the biosynthesis of bile acid, steroid hormones, and vitamin D (170). Increased cholesterol levels in the serum facilitate the development of coronary atherosclerosis (Berliner and Heinecks 1996). In addition, TG is a major component of chylomicron and very low-density lipoprotein (VLDL), both of which are energy substrates for liver and peripheral tissue, particularly, muscles. High levels of TG are a risk factor for atherosclerosis (John et al., 2005). In the present study, the metabolic and pharmacological effects of $H$. cunriformis was investigated. Blood lipids, cholesterol and triglycerides were shown to be decreased after the administration of the alga extract. This is an important finding since decreased levels of cholesterol and total lipids minimize the incidence of many cardiovascular problems (Uma et al., 2011). The use of marine alga as a diet may be responsible for the relatively normal ranges of lipid profile in this region (Al-Harthi and El-Deek, 2012). Literature survey indicates that alga contain unsaturated fatty acids more than saturated fatty acid, the main fatty acid being cholesterol and many other sterols (Aliya et al., 1991). Ingestion of diets containing highly unsaturated fatty acids has been shown to depress blood cholesterol level (Li et al., 2008). Also, Ahmed et al. (1993) reported the antihypertensive effects of seaweeds contain unsaturated fatty acids more than saturated fatty acid, the main fatty acid being cholesterol and many other sterols. Ingestion of diets containing highly unsaturated fatty acids has been shown to depress blood cholesterol level (Li et al., 2008).

The results indicated that the decrease in the concentration of triglycerol in the serum by dietary of the two algae was due to the promotion of fatty acid oxidation in rat liver. Since the increase in the concentration of triglycerol in the serum leads to the increase of the incidence of arteriosclerosis. Algae may play a role in the prevention of arteriosclerosis. It is harmony with finding of Murata and Nakazoe (2001), who report the dietary of Wakame is associated with the promotionoxidation of fatty acids in the liver and serum and subsequently play a role in the prevention and treatment of arteriosclerosis. An abundance of evidence strongly suggests that increased intakes of long chain omega-3 fatty acids can markedly reduce the risk of heart disease. The omega-3 fatty acids (indicates that the first double bond is located at the third carbon from the end of the fatty acid chain) such as docosahexaenoic acid (DHA), eicosapentaenoic acid (EPA) and alpha-linolenic acid (ALA), believed to be largely responsible for their effects. These "good fats" are naturally present in some marine algae. Omega-3 fatty acids may help prevent heart disease through a number of different mechanisms. Omega-3 fatty acids also reduce the tendency to thrombosis (formation of blood clots), and thus help prevent myocardial infarction. EPA and DHA also have several actions that inhibit the development of atherosclerosis. While these fatty acids do not lower plasma cholesterol levels, they do have a substantial triglyceride-lowering effect and also raise levels of HDL "good cholesterol" (Connor2001). FT-IR spectrum of powder and ethanolic extract of powder and ethanolic extract of $H$. cuneiformis showed indicate the presence of aromatic and aliphatic amines, hydroxyl sulfonate, amino, and chloroalkanes. Furthermore, the phyco-chemical analysis of this alga reported the presence of proteins, vitamins, flavonoids, terpenoids, carotenoids, lignin, sterols, peptides and polysaccharides. Many of these compounds such as flavonoids, polysaccharides (fucodian), vitamins and terpenoids are powerful antioxidants. It was known that marine algae contain numerous bioactive substances that have been shown to lower cholesterol, reduce blood pressure, and promote healthy digestion and antioxidant activity (Fung et al., 2013). The sulphur compounds in the extracts are capable of reducing the excessive accumulation of intracellular triglycerides (Dianzani, 1978). 


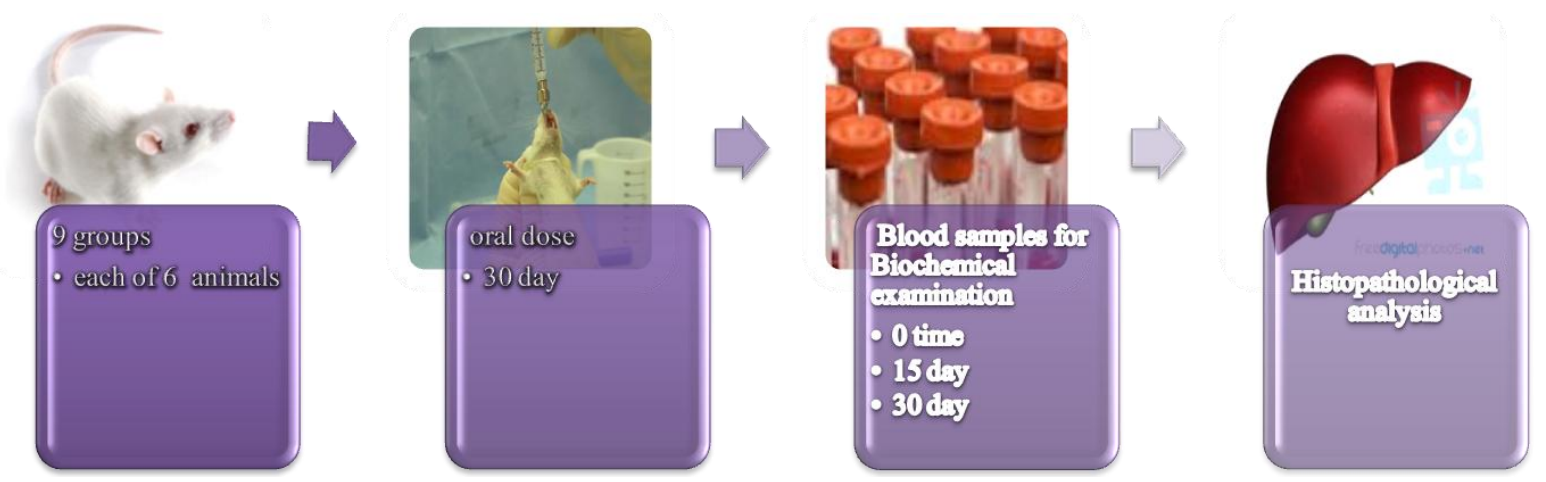

Fig. 2: The protocol diagram illustrates the collection of blood samples and histopathology.

Table 2: Effect of H. cuneiformis ethanolic extract on Cholesterol (TC) and Triglycerides (TG) (mg/dl) of ethanol-administered rats.

\begin{tabular}{|c|c|c|c|c|c|c|}
\hline \multirow[b]{2}{*}{$\begin{array}{c}\text { Groups } \\
\text { Treatments }\end{array}$} & \multicolumn{3}{|c|}{ Cholesterol (mg/dl) } & \multicolumn{3}{|c|}{ Triglycerides (mg/dl) } \\
\hline & $\begin{array}{l}\text { Zero } \\
\text { Time }\end{array}$ & $\begin{array}{c}15 \\
\text { day }\end{array}$ & $\begin{array}{c}30 \\
\text { day }\end{array}$ & $\begin{array}{l}\text { Zero } \\
\text { Time }\end{array}$ & $\begin{array}{c}15 \\
\text { day }\end{array}$ & $\begin{array}{c}\text { 30 } \\
\text { day }\end{array}$ \\
\hline Control & $58.02 \pm 2.61$ & $59.31 \pm 0.55$ & $61.25 \pm 1.45$ & $36.64 \pm 1.66$ & $36.70 \pm 1.42$ & $36.34 \pm 3.20$ \\
\hline $10 \%$ Ethanol & $60.31 \pm 2.33$ & $\begin{array}{c}71.52 \pm 2.01 * * \\
(18.59 \% \uparrow)\end{array}$ & $\begin{array}{c}78.62 \pm 3.45 * * \\
(30.36 \% \uparrow)\end{array}$ & $59.50 \pm 1.00$ & $\begin{array}{c}64.80 \pm 5.50 * \\
(8.91 \% \uparrow)\end{array}$ & $\begin{array}{c}70.55 \pm 4.23 * * \\
(59.07 \% \uparrow)\end{array}$ \\
\hline $25 \%$ Ethanol & $60.41 \pm 1.74$ & $\begin{array}{c}75.84 \pm 3.62 * * \\
(25.54 \% \uparrow)\end{array}$ & $\begin{array}{c}81.31 \pm 5.45 * * \\
\quad(34.60 \% \uparrow)\end{array}$ & $64.08 \pm 2.11$ & $\begin{array}{c}78.00 \pm 5.24 * * \\
\quad(21.72 \% \uparrow)\end{array}$ & $\begin{array}{c}86.43 \pm 5.23 * * \\
\quad(70.79 \% \uparrow)\end{array}$ \\
\hline $10 \%$ Ethanol + Alga extract & $61.04 \pm 2.11$ & $\begin{array}{c}64.23 \pm 2.14 \\
(5.23 \% \uparrow)\end{array}$ & $\begin{array}{c}62.92 \pm 4.32 \\
(3.08 \% \uparrow)\end{array}$ & $49.40 \pm 1.30$ & $\begin{array}{c}52.45 \pm 4.00 \\
(6.17 \% \uparrow)\end{array}$ & $\begin{array}{c}53.76 \pm 3.21 \\
(8.83 \% \uparrow)\end{array}$ \\
\hline 25\% Ethanol + Alga extract & $54.75 \pm 1.64$ & $\begin{array}{c}55.51 \pm 1.41 \\
(1.37 \% \uparrow)\end{array}$ & $\begin{array}{c}53.51 \pm 1.41 \\
(2.27 \% \downarrow)\end{array}$ & $52.70 \pm 2.40$ & $\begin{array}{c}54.77 \pm 1.45 \\
(3.93 \% \uparrow)\end{array}$ & $\begin{array}{c}56.55 \pm 3.01 \\
(7.31 \% \uparrow)\end{array}$ \\
\hline Alga extract & $59.85 \pm 1.44$ & $\begin{array}{c}57.03 \pm 2.85 \\
(4.71 \% \downarrow)\end{array}$ & $\begin{array}{c}54.04 \pm 2.14 \\
(9.71 \% \downarrow)\end{array}$ & $53.50 \pm 2.01$ & $\begin{array}{c}54.66 \pm 2.84 \\
(2.17 \% \uparrow)\end{array}$ & $\begin{array}{c}54.85 \pm 3.54 \\
(2.52 \% \uparrow)\end{array}$ \\
\hline
\end{tabular}

All values are mean $\pm \mathrm{SD}, \mathrm{n}=6, * \mathrm{P}<0.05, * * \mathrm{P}<0.01$ when compared by the values at zero time (one way ANOVA followed by Dunnett's test); Number in the parenthesis indicates $\%$ decrease or increase in the respective serum levels. $\uparrow$ denotes increase, $\downarrow$ denotes decrease.

Table 3 Effect of $H$. cuneiformis ethanolic extract on HDL, LDL of cholesterol induced hyperlipidemic rats.

\begin{tabular}{|c|c|c|c|c|c|c|}
\hline \multirow[b]{2}{*}{$\begin{array}{c}\text { Groups } \\
\text { Treatments }\end{array}$} & \multicolumn{3}{|c|}{ HDL (mg/dl) } & \multicolumn{3}{|c|}{ LDL (mg/dl) } \\
\hline & $\begin{array}{l}\text { Zero } \\
\text { Time }\end{array}$ & $\begin{array}{c}15 \\
\text { day }\end{array}$ & $\begin{array}{c}30 \\
\text { day }\end{array}$ & $\begin{array}{l}\text { Zero } \\
\text { Time }\end{array}$ & $\begin{array}{c}15 \\
\text { day }\end{array}$ & $\begin{array}{c}30 \\
\text { day }\end{array}$ \\
\hline Control & $27.23 \pm 0.56$ & $28.44 \pm 1.02$ & $28.09 \pm 1.02$ & $39.44 \pm 1.24$ & $39.50 \pm 1.05$ & $39.41 \pm 0.89$ \\
\hline $10 \%$ Ethanol & $34.25 \pm 0.66$ & $\begin{array}{c}27.20 \pm 0.56 * \\
(20.58 \% \downarrow)\end{array}$ & $\begin{array}{c}20.00 \pm 0.64 * * \\
\quad(41.61 \% \downarrow)\end{array}$ & $34.00 \pm 0.55$ & $\begin{array}{c}40.65 \pm 1.80 * \\
(19.56 \% \uparrow)\end{array}$ & $\begin{array}{c}54.51 \pm 1.05 * * \\
(60.32 \% \uparrow)\end{array}$ \\
\hline 25\% Ethanol & $41.00 \pm 0.78$ & $\begin{array}{c}24.00 \pm 1.00 * * \\
\quad(41.46 \% \downarrow)\end{array}$ & $\begin{array}{c}22.64 \pm 0.54 * * \\
\quad(44.78 \% \downarrow)\end{array}$ & $37.54 \pm 1.08$ & $\begin{array}{c}54.84 \pm 1.35 * * \\
\quad(46.08 \% \uparrow)\end{array}$ & $\begin{array}{c}66.46 \pm 2.34 * * \\
\quad(77.04 \% \uparrow)\end{array}$ \\
\hline $10 \%$ Ethanol + Alga extract & $42.50 \pm 0.85$ & $\begin{array}{c}39.55 \pm 0.54 \\
(6.94 \% \downarrow)\end{array}$ & $\begin{array}{c}41.02 \pm 1.22 \\
(3.48 \% \downarrow)\end{array}$ & $52.52 \pm 1.32$ & $\begin{array}{c}53.00 \pm 2.50 \\
(0.91 \% \uparrow)\end{array}$ & $\begin{array}{c}52.00 \pm 3.40 \\
(0.99 \% \downarrow)\end{array}$ \\
\hline 25\% Ethanol + Alga extract & $38.05 \pm 0.49$ & $\begin{array}{c}35.50 \pm 1.03 \\
(6.70 \% \downarrow)\end{array}$ & $\begin{array}{c}34.02 \pm 1.34 \\
(10.59 \% \downarrow)\end{array}$ & $46.54 \pm 1.07$ & $\begin{array}{c}47.02 \pm 1.02 \\
(1.03 \% \uparrow)\end{array}$ & $\begin{array}{c}48.45 \pm 2.05 \\
\quad(4.10 \% \uparrow)\end{array}$ \\
\hline Alga extract & $45.00 \pm 0.62$ & $\begin{array}{c}55.00 \pm 2.00 * * \\
(22.22 \% \uparrow)\end{array}$ & $\begin{array}{c}50.00 \pm 2.54 * \\
(11.11 \% \uparrow)\end{array}$ & $55.00 \pm 2.74$ & $\begin{array}{c}50.50 \pm 2.03 * \\
(8.18 \% \downarrow)\end{array}$ & $\begin{array}{c}50.00 \pm 2.00 * \\
(9.09 \% \downarrow)\end{array}$ \\
\hline
\end{tabular}

All values are mean $\pm \mathrm{SD}, \mathrm{n}=6, * \mathrm{P}<0.05, * * \mathrm{P}<0.01$ when compared by the values at zero time (one way ANOVA followed by Dunnett's test); Number in the parenthesis indicates $\%$ decrease or increase in the respective serum levels. $\uparrow$ denotes increase, $\downarrow$ denotes decrease.

Effect of $H$. cuneiformis extract on the HDL

Concerning the comparison between the data recorded in Table 3, we found that, HDL levels were decreased in groups (2-5) compared with control group ( $1^{\text {st }}$ group). Whereas, HDL levels were significantly $(\mathrm{P}<0.05)$ decreased to $20.58 \%$ and highly significantly $(\mathrm{P}<0.01)$ decreased to $41.61 \%$ in the $2^{\text {nd }}$ group by the day 15 and 30, respectively. Furthermore, HDL levels in the rats of the $3^{\text {rd }}$ group were significantly $(\mathrm{P}<0.01)$ decreased by 41.46 and $44.78 \%$ at the end of 15 and 30 day, respectively. On the other hand, the members of the fourth and fifth groups were exhibit insignificant decreasing in the DHL levels by $6.94,3.48 \%$ in the fourth group and by 6.7 , and $10.59 \%$ in the fifth group at the end of days 15 and 30, respectively. Also, the treatment of the rats (which preciously injected by 10 or $25 \%$ ) by $H$. cuneiformis extract in the fourth and fifth groups caused highly suppression in the ethanol action by 13.64 and $38.13 \%$ in the fourth group and by 34.76 and $34.19 \%$ in the fifth group at the end of 15 and 30 day, respectively. In contrast, the sixth group revealed a significant increasing in DHL levels at $\mathrm{P}<0.01$ reached $22.22 \%$ in the day 15 and $11.11 \%$ at $\mathrm{P}<0.05$ in the end of day 30 .

\section{Effect of $H$. cuneiformis extract on the LDL}

Concerning the LDL levels in the experimental rats in the six groups (Table 3), we found that the results of groups (2-6) exhibit a significant increasing in the proportion of LDL level in most treatments. It reached significant increasing reached $19.56 \%$ 
at $\mathrm{P}<0.05$ after 15 days of injections for the second group which reached $60.32 \%$ at $\mathrm{P}<0.01$ after 30 days of injections, while these levels increased significantly $(\mathrm{P}<0.01)$ with the members of the third group reached 46.08 and $77.04 \%$ after 15, 30 days of injection, respectively. Excludes from this elevation in the LDL level that happened within members of the sixth group who's injected by $H$. cuneiformis extract. This group exhibit significant decreasing in their LDL levels $(\mathrm{P}<0.05)$ arrived 8.18, 9.08\% after 15,30 days, respectively. On the other hand, the injection of the fourth and fifth groups with extract of $H$. cuneiformis (which has already injected with ethanol by 10 or $25 \%$ ) decrease the negative impact of ethanol on LDL levels reached 18.65, 59.33\% and $45.05,72.94 \%$ in the fourth and fifth group after 15, 30 days of injection, respectively.

\section{Effect of $\boldsymbol{H}$. cunriformis ethanolic extract on various biological parameters of cholesterol induced hyperlipidemic rats.}

Regarding the biological indexes for the cholesterol induced hyperlipidemic rats, we found that the groups (4-6) treated with the extract of $H$. cuneiformis demonstrated significant decrease in the Atherogenic index and LDL/HDL risk factor when compared to cholesterol induced hyperlipidemic groups $(2,3)$ (see Table 4). The extracts of the two studied algae induced an increase in serum HDL levels in the hyperlipidemic models. During blood circulation, HDL mediates the transfer excess cholesterol from the peripheral cells to the liver for its catabolism by a pathway termed as "reverse cholesterol transport" hence increased serum HDL levels may prove beneficial in lipid disorders and might also serve as a cardio-protective factor to prevent the gradual initiation of atherosclerotic process.

Table. 4: Effect of H. cuneiformis ethanolic extract on Atherogenic Index (AI) and Risk Factor after 30 days of treatment in ethanol-administered rats.

\begin{tabular}{ccc}
\hline $\begin{array}{c}\text { Groups } \\
\text { Treatments }\end{array}$ & $\begin{array}{c}\text { Atherogenic Index } \\
\text { TC / HDL }\end{array}$ & $\begin{array}{c}\text { Risk Factor } \\
\text { LDL / HDL }\end{array}$ \\
\hline Control & 2.18 & 1.4 \\
10\% Ethanol & 3.93 & 2.73 \\
25\% Ethanol & 3.59 & 2.94 \\
10\% Ethanol + Alga extract & 1.53 & 1.27 \\
25\% Ethanol + Alga extract & 1.57 & 1.42 \\
Alga extract & 1.08 & 1.00 \\
\hline
\end{tabular}

According to many studies, LDL-C is the most important factor among the serum lipids. For example, LDL-C is known to accumulate in the extracellular sub-endothelial space of arteries and to be toxic to arterial walls (Rota et al.,1998). Furthermore, elevated LDL-C levels play a crucial role in the development of atherosclerosis lesions that progress from fatty steaks to ulcerated plaques. Therefore, the serum level of LDL-C is used as the basis for initiating and monitoring the treatment of patients with elevated blood cholesterol levels (Schaefer et al.,1995). Thus, lowering the abnormally increased serum triglyceride, as well as the TC and LDLC levels, reduces the incidence of atherosclerosis. The AI which is the ratio of LDL-C to HDL-C, is commonly used as an index to evaluate the risk for atherosclerosis as a result of increased HDL-C levels (Fki et al.,2005). Therefore, elevating the level of HDL-C and lowering the AI are important measures in reducing the risk of atherosclerosis. HDL-C exerts an antiatherogenic effect by counteracting LDL-C oxidation and facilitating the translocation of cholesterol from peripheral tissue such as arterial walls to the liver for catabolism (Choi et al.,1991). The induction of hyperlipidemia by a high-cholesterol diet in experimental animals has long been used to assess the beneficial effects of hyperlipidemic agents on the regulation of cholesterol (Yokozawa et al.,2006).

\section{Effect of $H$. cuneiformis ethanolic extract on the levels of ALT}

Serum marker enzyme in ethanol-treated rats groups $(G$ 2 and 3) compared to control group (G1) showed significant $(\mathrm{P}<0.01)$ increase in serum ALT by 32.39, $48.19 \%$ and 47.42, $42.51 \%$ for G2 and G 3 on day 15 and 30, respectively (Table 5). The activities of ALT rats fed simultaneously with ethanol and $H$. cuneiformis ethanolic extract (G4 and G5) exhibit insignificant increase in the serum ALT by 4.2 and $7.52 \%$ in the G4 after 15 and 30 days of treatment, respectively. Meanwhile in the case of G5, the level of serum ALT showed reduction by $2.47 \%$ after 15 days followed by an elevation to $2.13 \%$ on day 30 . On the other hand, the activity of ALT in the rats fed only with $H$. cuneiformis extract showed marked reduction by $6.42 \%$ after 15 days followed by slightly increasing by $0.22 \%$ on the day 30 . Furthermore, the treatment of the G4 and G5 by the $H$. cuneiformis extract showed marked reduction in the ethanol action by $28.19,40.67 \%$ in G4 and by $49.89,40.38 \%$ in G5 after 15 and 30 days, respectively.

\section{Effect of $\boldsymbol{H}$. cuneiformis ethanolic extract on the levels of AST}

Regarding the AST levels of the treated groups as indicated in Table 5, we found that groups 2 and 3 exhibit significant $(\mathrm{P}<0.01)$ increasing reached 30.70, $72.80 \%$ and 34.41 , $65.35 \%$ after 15 and 30 days of injection, respectively. While, the fourth group exhibit significant $(\mathrm{P}<0.05)$ increase in AST levels reached $10.22 \%$ and insignificant increase reached 2.59 after 15 , 30 days, respectively. By the same manner, the fifth group exhibit insignificant increase reached $8.13 \%$ after the day 15 , but appeared insignificant decreasing in the AST level reached $1.97 \%$ after the day 30. On the other hand, the sixth group revealed insignificant decreasing in the AST level reached 4.39 and $6.55 \%$ after 15 and 30 days of treatment, respectively. Furthermore, the treatment of the G4 and G5 by the H. cuneiformis extract showed marked reduction in the ethanol action by 20.48, 70.21\% in G4 and by $26.28,67.28 \%$ in G5 after 15 and 30 days, respectively.

Regarding the ratio of serum alanine aminotransferase (ALT) to serum aspartase aminotransferase (AST), it was found that the ethanol-treated rats exhibit a decreasing values (ALT/AST $<1$ ), severe hepatic or alcoholic hepatic disease. On the other hand, this ratio exhibit normal values with rats fed simultaneously with ethanol and $H$. cuneiformis extract $(2<\mathrm{ALT} / \mathrm{AST}>1)$ which referred to normal individuals. The liver enzymes are normally found in circulation in small amounts because of hepatic growth and repair. ALT and AST activities were elevated in hypercholesterolemic groups, meanwhile, the treated groups 
Table 5: Effect of ethanol extract of H. cuneiformis ethanolic extracts on serum hepatic markers of ALT and AST (U/L) ethanol-administered rats and ALT/AST ratio.

\begin{tabular}{|c|c|c|c|c|c|c|c|c|}
\hline \multirow{2}{*}{\multicolumn{2}{|c|}{$\begin{array}{c}\text { Groups } \\
\text { Treatments }\end{array}$}} & \multicolumn{3}{|c|}{ ALT (U/L) } & \multicolumn{3}{|c|}{ AST (U/L) } & \multirow{2}{*}{$\begin{array}{c}\text { ALT/AST } \\
\text { Ratio }\end{array}$} \\
\hline & & $\begin{array}{l}\text { Zero } \\
\text { Time }\end{array}$ & $\begin{array}{c}15 \\
\text { day }\end{array}$ & $\begin{array}{c}30 \\
\text { day }\end{array}$ & $\begin{array}{l}\text { Zero } \\
\text { Time }\end{array}$ & $\begin{array}{c}15 \\
\text { day }\end{array}$ & $\begin{array}{c}30 \\
\text { day }\end{array}$ & \\
\hline & Control & $59.64 \pm 1.42$ & $58.13 \pm 1.20$ & $57.68 \pm 1.52$ & $54.31 \pm 0.35$ & $54.35 \pm 1.05$ & $56.35 \pm 1.09$ & 1.33 \\
\hline & $10 \%$ Ethanol & $58.35 \pm 0.58$ & $\begin{array}{c}77.25 \pm 1.25 * * \\
(32.39 \% \uparrow)\end{array}$ & $\begin{array}{c}86.45 \pm 2.81 * * \\
\quad(48.19 \% \uparrow)\end{array}$ & $52.32 \pm 0.54$ & $\begin{array}{c}68.38 \pm 2.02 * * \\
(30.70 \% \uparrow)\end{array}$ & $\begin{array}{c}90.41 \pm 1.04 * * \\
(72.80 \% \uparrow)\end{array}$ & 0.96 \\
\hline & $25 \%$ Ethanol & $63.45 \pm 2.34$ & $\begin{array}{c}93.54 \pm 3.24 * * \\
(47.42 \% \uparrow)\end{array}$ & $\begin{array}{l}90.42 \pm 2.64 * * \\
\quad(42.51 \% \uparrow)\end{array}$ & $58.33 \pm 0.76$ & $\begin{array}{c}78.40 \pm 2.03 * * \\
(34.41 \% \uparrow)\end{array}$ & $\begin{array}{c}96.45 \pm 1.06 * * \\
(65.35 \% \uparrow)\end{array}$ & 0.94 \\
\hline $10 \%$ & Ethanol + Alga extract & $48.52 \pm 0.55$ & $\begin{array}{c}50.56 \pm 1.65 \\
(4.20 \% \uparrow)\end{array}$ & $\begin{array}{c}52.17 \pm 0.68 \\
(7.52 \% \uparrow)\end{array}$ & $39.32 \pm 0.05$ & $\begin{array}{c}43.34 \pm 1.04^{*} \\
(10.22 \% \uparrow)\end{array}$ & $\begin{array}{c}40.34 \pm 1.04 \\
(2.59 \% \uparrow)\end{array}$ & 1.49 \\
\hline $25 \%$ & Ethanol + Alga extract & $53.44 \pm 1.40$ & $\begin{array}{c}52.12 \pm 0.85 \\
(2.47 \% \downarrow)\end{array}$ & $\begin{array}{c}55.31 \pm 1.52 \\
(2.13 \% \uparrow)\end{array}$ & $49.34 \pm 0.08$ & $\begin{array}{c}53.35 \pm 2.06 \\
(8.13 \% \uparrow)\end{array}$ & $\begin{array}{c}48.37 \pm 1.08 \\
(1.97 \% \downarrow)\end{array}$ & 1.14 \\
\hline & Alga extract & $63.20 \pm 1.07$ & $\begin{array}{c}59.14 \pm 0.15 \\
(6.42 \% \downarrow)\end{array}$ & $\begin{array}{c}63.34 \pm 1.50 \\
(0.22 \% \uparrow)\end{array}$ & $45.35 \pm 0.04$ & $\begin{array}{c}43.36 \pm 1.03 \\
(4.39 \% \downarrow)\end{array}$ & $\begin{array}{c}42.38 \pm 0.85 \\
(6.55 \% \downarrow)\end{array}$ & 1.50 \\
\hline
\end{tabular}

All values are mean $\pm \mathrm{SD}, \mathrm{n}=6,{ }^{*} \mathrm{P}<0.05, * * \mathrm{P}<0.01$ when compared by the values at zero time (one way ANOVA followed by Dunnett's test); Number in the parenthesis indicates $\%$ decrease or increase in the respective serum levels. $\uparrow$ denotes increase, $\downarrow$ denotes decrease.

showed an obvious enhancement (Sudhahar et al.,2007). The increasing in the levels of diagnostic marker enzymes (ALT and AST) in plasma of ethanol-feeding rats as compared to that of Group I (control rats) is indicative of the cellular leakages and loss of functional integrity of cell membrane in liver. The present observation is in agreement with earlier reported studies (Kume et $a l ., 2006)$, which have shown that the amount of diagnostic marker enzymes present in plasma is directly proportional to the number of necrotic cells present in the liver tissue.

Oral pre-treatment with the two algal extracts attenuated the EtOH-induced elevation in the levels of these diagnostic marker enzymes in plasma of Group II and III animals as compared to other groups of rats, demonstrating the cytoprotective activity of the two algae. These findings indicated that the ethanol extract of the two algae preserved the structural integrity of the hepatocellular membrane and liver cell architecture damage caused by $\mathrm{EtOH}$. Previous studies have shown that natural antioxidant molecules impart stabilization to cell membranes in relation to the degree of their free radical scavenging ability (Ganesan et al., 2007).

Hence, it is possible that likewise the two algae may also prolong the viability of liver cell membranes from EtOH -induced necrotic damage by its membrane stabilizing action.

\section{Effect of $\boldsymbol{H}$. cuneiformis extract on the serum protein-profile of ethanol-administrated rats}

\section{Effect of $H$. cuneiformis extract on the protein contents.}

There was a significant $(\mathrm{P}<0.001)$ decrease in the rate of protein contents (Table 6) for the second group reached $94.68 \%$ after 15 days and $(\mathrm{P}<0.05)$ reached $47.74 \%$ after 30 days. Also the $3^{\text {rd }}$ group showed a significant $(\mathrm{P}<0.01)$ reduction in protein content reached 52.63, 58.90\% after 15, 30 days of treatment.

The results also showed that the rate of protein decreased significantly $(\mathrm{P}<0.05)$ in the $4^{\text {th }}$ group to $23.59 \%$ after 15 days, so that level was decline to reach $12.58 \%$ only after 30 days of treatment. Furthermore, Group 5 showed a decrease in the rate of protein degree to $13.64,3.41 \%$ after 15,30 days, respectively. On contrary, sixth group showed significant $(\mathrm{P}<0.01)$ increase in the rate of protein reached $51.09 \%$ after 15 days and significant ( $\mathrm{P}<0.001)$ increase reached $126.73 \%$ after 30 days of treatment.

Table. 6: Effect of ethanol extract of $H$. cuneiformis ethanolic extract on serum protein profile $(\mathrm{mg} / \mathrm{dl})$ of ethanol-administered rats.

\begin{tabular}{lccc}
\hline \multirow{2}{*}{$\begin{array}{c}\text { Groups } \\
\text { Treatments }\end{array}$} & \multicolumn{3}{c}{ Total proteins (mg/dl) } \\
\cline { 2 - 4 } & Time & $\begin{array}{c}\mathbf{1 5} \\
\text { day }\end{array}$ & $\begin{array}{c}\mathbf{3 0} \\
\text { day }\end{array}$ \\
\hline \multicolumn{1}{c}{ Control } & $8.53 \pm 0.04$ & $8.20 \pm 0.01$ & $8.23 \pm 0.05$ \\
$10 \%$ Ethanol & $8.86 \pm 0.08$ & $5.30 \pm 0.03 * * *$ & $4.63 \pm 0.03 *$ \\
& & $(94.68 \% \downarrow)$ & $(47.74 \% \downarrow)$ \\
25\% Ethanol & $8.93 \pm 0.03$ & $4.23 \pm 0.07 * *$ & $3.67 \pm 0.09 * *$ \\
10\% Ethanol + Alga & & $(52.63 \% \downarrow)$ & $(58.90 \% \downarrow)$ \\
extract & $8.90 \pm 0.03$ & $6.80 \pm 0.01 *$ & $7.78 \pm 0.04$ \\
25\% Ethanol + & & $(23.59 \% \downarrow)$ & $(12.58 \% \downarrow)$ \\
Alga extract & $8.80 \pm 0.05$ & $7.60 \pm 0.05$ & $8.50 \pm 0.08$ \\
Alga extract & & $(13.64 \% \downarrow)$ & $(3.41 \% \downarrow)$ \\
& $5.50 \pm 0.06$ & $8.31 \pm 0.06 * *$ & $12.47 \pm 0.06 * * *$ \\
& & $(51.09 \% \uparrow)$ & $(126.73 \% \uparrow)$ \\
\hline All
\end{tabular}

All values are mean $\pm \mathrm{SD}, \mathrm{n}=6, * \mathrm{P}<0.05, * * \mathrm{P}<0.01, * * * \mathrm{P}<0.001 \quad$ when compared by the values at zero time (one way ANOVA followed by Dunnett's test); Number in the parenthesis indicates \% decrease or increase in the respective serum levels. $\uparrow$ denotes increase, $\downarrow$ denotes decrease.

\section{Effect of $\boldsymbol{H}$. cuneiformis extract on the albumin contents}

The results recorded in Table 7 revealed a significant $(\mathrm{P}$ $<0.05)$ decrease in the albumin contents of the second group reached $41.51,47.17 \%$, while the third group showed a significant ( $\mathrm{P}<0.01)$ reduction to 55.93 and $66 \%$ after 15 and 30 days, respectively. The members of the fourth and fifth groups showed a significant $(\mathrm{P}<0.05)$ decrease reached 31.03, 25.86\% for the fourth group and $14.82,3.7 \%$ for the fifth group after 15, 30 days of treatment, respectively.

On the other hand Group 6 showed insignificant increase in the rate of albumin reached $15.9 \%$ after 15 days, while this increased to reach a significant $(\mathrm{P}<0.001)$ degree by $100 \%$ after 30 days.

\section{Effect of $\boldsymbol{H}$. cuneiformis extracts on the globulin contents}

Regarding the globulin contents within the experimental rats (Table 7$)$, there is a significant $(\mathrm{P}<0.05)$ decrease in the rate globulin in the second and third groups reached 38.2, $48.59 \%$ and $46.21,41.91 \%$ after 15, 30 days for the two groups, respectively. 
Table 7: Effect of H. cuneiformis ethanolic extract on albumin and globulin contents of ethanol-administered rats.

\begin{tabular}{|c|c|c|c|c|c|c|c|}
\hline \multirow{2}{*}{\multicolumn{2}{|c|}{$\begin{array}{c}\text { Groups } \\
\text { Treatments }\end{array}$}} & \multicolumn{3}{|c|}{ Albumin (mg/dl) } & \multicolumn{3}{|c|}{ Globulin (mg/dl) } \\
\hline & & $\begin{array}{l}\text { Zero } \\
\text { Time }\end{array}$ & $\begin{array}{c}15 \\
\text { day }\end{array}$ & $\begin{array}{c}30 \\
\text { day }\end{array}$ & $\begin{array}{l}\text { Zero } \\
\text { Time }\end{array}$ & $\begin{array}{c}15 \\
\text { day }\end{array}$ & $\begin{array}{c}30 \\
\text { day }\end{array}$ \\
\hline & Control & $5.30 \pm 0.04$ & $5.20 \pm 0.04$ & $5.30 \pm 0.05$ & $3.33 \pm 0.08$ & $3.00 \pm 0.01$ & $3.93 \pm 0.02$ \\
\hline & $10 \%$ Ethanol & $5.30 \pm 0.05$ & $\begin{array}{c}3.10 \pm 0.08 * \\
(41.51 \% \downarrow)\end{array}$ & $\begin{array}{c}2.80 \pm 0.09 * \\
(47.17 \% \downarrow)\end{array}$ & $3.56 \pm 0.04$ & $\begin{array}{c}2.20 \pm 0.04 * \\
(38.2 \% \downarrow)\end{array}$ & $\begin{array}{c}1.83 \pm 0.01 * \\
(48.59 \% \downarrow)\end{array}$ \\
\hline & $25 \%$ Ethanol & $5.90 \pm 0.04$ & $\begin{array}{c}2.60 \pm 0.02 * * \\
(55.93 \% \downarrow)\end{array}$ & $\begin{array}{c}2.00 \pm 0.08 * * \\
(66 \% \downarrow)\end{array}$ & $3.03 \pm 0.05$ & $\begin{array}{c}1.63 \pm 0.02 * \\
(46.21 \% \downarrow)\end{array}$ & $\begin{array}{c}1.76 \pm 0.04 * \\
(41.91 \% \downarrow)\end{array}$ \\
\hline $10 \%$ & Ethanol + Alga extract & $5.80 \pm 0.02$ & $\begin{array}{c}4.00 \pm 0.01^{*} \\
(31.03 \% \downarrow)\end{array}$ & $\begin{array}{c}4.30 \pm 0.02 * \\
(25.86 \% \downarrow)\end{array}$ & $3.10 \pm 0.03$ & $\begin{array}{c}2.80 \pm 0.05 \\
(9.68 \% \downarrow)\end{array}$ & $\begin{array}{l}3.48 \pm 0.06 \\
(12.26 \% \uparrow)\end{array}$ \\
\hline $25 \%$ & Ethanol + Alga extract & $5.40 \pm 0.04$ & $\begin{array}{c}4.60 \pm 0.04 \\
(14.82 \% \downarrow)\end{array}$ & $\begin{array}{c}5.20 \pm 0.05 \\
(3.7 \% \downarrow)\end{array}$ & $3.40 \pm 0.04$ & $\begin{array}{c}3.00 \pm 0.04 \\
(11.77 \% \downarrow)\end{array}$ & $\begin{array}{c}3.30 \pm 0.05 \\
(2.94 \% \downarrow)\end{array}$ \\
\hline & Alga extract & $3.90 \pm 0.06$ & $\begin{array}{c}4.52 \pm 0.06 * \\
(15.90 \% \uparrow)\end{array}$ & $\begin{array}{c}7.80 \pm 0.01 * * * \\
(100 \% \uparrow)\end{array}$ & $2.60 \pm 0.01$ & $\begin{array}{c}3.79 \pm 0.07 * \\
(45.77 \% \uparrow)\end{array}$ & $\begin{array}{c}4.67 \pm 0.03 * * \\
(79.62 \% \uparrow)\end{array}$ \\
\hline
\end{tabular}

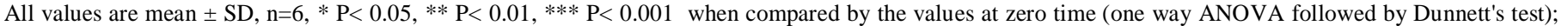
Number in the parenthesis indicates \% decrease or increase in the respective serum levels. $\uparrow$ denotes increase, $\downarrow$ denotes decrease.

Table 8: Effect of H. cuneiformis ethanolic extract on the serum BUN and creatinine (mg/dl) of ethanol-administered rats.

\begin{tabular}{|c|c|c|c|c|c|c|c|}
\hline \multirow{3}{*}{\multicolumn{2}{|c|}{$\begin{array}{c}\text { Groups } \\
\text { Treatments }\end{array}$}} & \multicolumn{3}{|c|}{ BUN (mg/dl) } & \multicolumn{3}{|c|}{ Creatinine (mg/dl) } \\
\hline & & Zero & 15 & 30 & Zero & 15 & 30 \\
\hline & & Time & day & day & Time & day & day \\
\hline & Control & $18.50 \pm 0.20$ & $19.41 \pm 0.20$ & $20.00 \pm 0.64$ & $0.31 \pm 0.05$ & $0.35 \pm 0.05$ & $0.35 \pm 0.09$ \\
\hline & $10 \%$ Ethanol & $20.08 \pm 0.27$ & $\begin{array}{c}34.63 \pm 0.14 * * \\
(73.15 \% \uparrow)\end{array}$ & $\begin{array}{c}29.44 \pm 0.85 * \\
\quad(47.2 \% \uparrow)\end{array}$ & $0.32 \pm 0.04$ & $\begin{array}{c}0.48 \pm 0.02 * * \\
(50 \% \uparrow)\end{array}$ & $\begin{array}{c}0.41 \pm 0.04 * \\
\quad(28.13 \% \uparrow)\end{array}$ \\
\hline & $25 \%$ Ethanol & $18.00 \pm 0.57$ & $\begin{array}{c}33.25 \pm 0.87 * * * \\
(84.72 \% \uparrow)\end{array}$ & $\begin{array}{c}29.50 \pm 0.41 * * \\
(63.89 \% \uparrow)\end{array}$ & $0.33 \pm 0.06$ & $\begin{array}{c}0.48 \pm 0.03 * \\
(45 \% \uparrow)\end{array}$ & $\begin{array}{c}0.40 \pm 0.06 * \\
\quad(21.21 \% \uparrow)\end{array}$ \\
\hline $10 \%$ & Ethanol + Alga extract & $18.00 \pm 0.56$ & $21.17 \pm 0.65$ & $17.41 \pm 0.12$ & $0.32 \pm 0.05$ & $0.34 \pm 0.04$ & $0.30 \pm 0.04$ \\
\hline & & & $(17.61 \% \uparrow)$ & $(3.28 \% \downarrow)$ & & $(6.25 \% \uparrow)$ & $(6.25 \% \downarrow)$ \\
\hline $25 \%$ & Ethanol + Alga extract & $16.40 \pm 0.02$ & $20.23 \pm 0.12 *$ & $17.04 \pm 0.76$ & $0.34 \pm 0.08$ & $0.35 \pm 0.06$ & $0.30 \pm 0.08$ \\
\hline & & & $(23.35 \% \uparrow)$ & $(3.9 \% \uparrow)$ & & $(2.94 \% \uparrow)$ & $(11.77 \% \downarrow)$ \\
\hline & Alga extract & $18.00 \pm 0.08$ & $19.41 \pm 0.85$ & $18.50 \pm 0.68$ & $0.35 \pm 0.04$ & $0.33 \pm 0.03$ & $0.34 \pm 0.05$ \\
\hline & & & $(7.8 \% \uparrow)$ & $(2.78 \% \uparrow)$ & & $(5.71 \% \downarrow)$ & $(2.86 \% \downarrow)$ \\
\hline
\end{tabular}

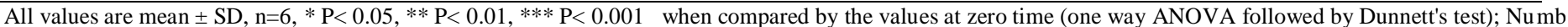
in the parenthesis indicates \% decrease or increase in the respective serum levels. $\uparrow$ denotes increase, $\downarrow$ denotes decrease.

Although the fourth group showed insignificant reduction in the globulin rate $(9.68 \%)$ after 15 days, but it showed insignificant increasing reached $12.26 \%$ after 30 days of treatment. On the other hand, Group 5 showed insignificant reduction in the rate of globulin to 10.77 and $2.94 \%$ after 15, 30 days of treatment, respectively. Meanwhile, the sixth group showed significant $(\mathrm{P}$ $<0.05$ ) increase in the globulin rate reached $45.77 \%$ after 15 days and significant $(\mathrm{P}<0.001)$ increase to $79.62 \%$ after 30 days of treatment. Albumin and globulin are two key components of serum proteins. Because albumin is synthesized in the liver, it is one element that is used to monitor the liver function (Friedman et al., 1980).

Decreased serum total protein, albumin and globulin are seen in ethanol-administered rats of our experiment run in parallel with the finding of (Abdel-Raouf et al.,2011). They demonstrated the decreased functional ability of ethanol-administered rat liver. Also, the decreased total protein concentration may be an indirect effect of the decreased albumin concentration. A significant increase in serum total protein, albumin and globulin levels was observed in algal extract co-administered rats. Stabilization of serum protein levels through the co-administration of $H$. cuneiformis extract is another additional clear indicationof the improvement of the functional status of the liver cells. Damage to the liver after ethanol ingestion is a well-known phenomenon, and the obvious sign of hepatic injury is the leakage of cellular enzymes into plasma (Baldi et al., 1993).

\section{Effect of $\boldsymbol{H}$. cuneiformis extract on the BUN and creatinine levels in blood serum \\ Effect of $H$. cuneiformis extract on the BUN}

Results in Table 8 indicated a significant $(\mathrm{P}<0.01)$ increase in the rate of BUN in Group 2 arrived $73.15 \%$ after 15 days and significant $(\mathrm{P}<0.05)$ increase reached $47.2 \%$ after 30 days. While the third group exhibit a significant $(\mathrm{P}<0.001)$ increase reached $84.72 \%$ after 15 days followed by a significant $(\mathrm{P}<0.01)$ increase reached $63.89 \%$ after 30 days. At the same time, Group 4 recorded insignificant increasing in BUN by $17.61 \%$ and a contrast ratio recorded reduction in BUN to $3.28 \%$ after 30 days. On the other hand, Group 5 recorded a significant $(\mathrm{P}<0.05)$ increase arrived $23.35 \%$ after 15 days which declined to $3.9 \%$ after 30 days, while the sixth group recorded insignificant increasing by 7.8 and $2.78 \%$ after 15 and 30 days, respectively. A blood urea nitrogen (BUN) test reveals important information about how well kidneys and liver are working.

A blood urea nitrogen test measures the amount of urea nitrogen that's in blood. Liver produces ammonia which contains nitrogen, after it breaks down proteins used by body cells. The nitrogen combines with other elements, such as carbon, hydrogen and oxygen, to form urea, which is a chemical waste product. The urea travels from liver to kidneys through blood stream. Healthy kidneys filter urea and other waste products from blood. The filtered waste products leave body in urine. If a blood urea 
nitrogen test reveals that urea nitrogen levels are higher than normal, it probably indicates that kidneys aren't working properly. Or it could point to high protein intake, inadequate fluid intake or poor circulation. If a blood urea nitrogen test shows lower than normal levels, it could indicate liver disease or damage, or malnutrition. But a low BUN level wouldn't likely be the first indication of liver disease because the blood urea nitrogen test isn't used as a screening test for that disorder.

\section{Effect of $H$. cuneiformis extract on the creatinine}

Regarding the creatinine rate in the experimental rates treated or untreated with $H$. cuneiformis (Table 8), we found that, Group 2 exhibit a significantly $(\mathrm{P}<0.01)$ increase reached $50 \%$ after 15 days and significant $(\mathrm{P}<0.05)$ increase reached $28.13 \%$ after 30 .

While the third group recorded significant $(\mathrm{P}<0.05)$ increase reached $45,21.21 \%$ after 15 and 30 days, respectively. In the same manner, Groups 4 and 5 showed insignificant increasing reached $6.25,2.94 \%$ after 15 days and comeback to fill down to 6.25 and $11.77 \%$ after the day 30, respectively. On the other hand, Group 6 showed a decline percentage in the creatinie level by 5.71, $2.86 \%$ after 15 and 30 days, respectively. Creatinine clearance calculated from creatinine concentrations in urine and plasma samples, and the urine flow rate, as well as urea clearance, is used to determine the glomerular filtration rate of the kidneys. Although not commonly done anymore, they remain useful tests for renal function.

Thus, plasma concentrations of creatinine and urea could be used as indicators of nephrotoxicity (Henry 2001). Low clearance of creatinine and/or urea indicates a diminished impaired ability of the kidneys to filter these waste products from the blood and excrete them in urine. As their clearance values decrease, their blood levels increase. Hence, an abnormally elevated blood creatinine is diagnostic of impaired renal function (Wallach 2000).

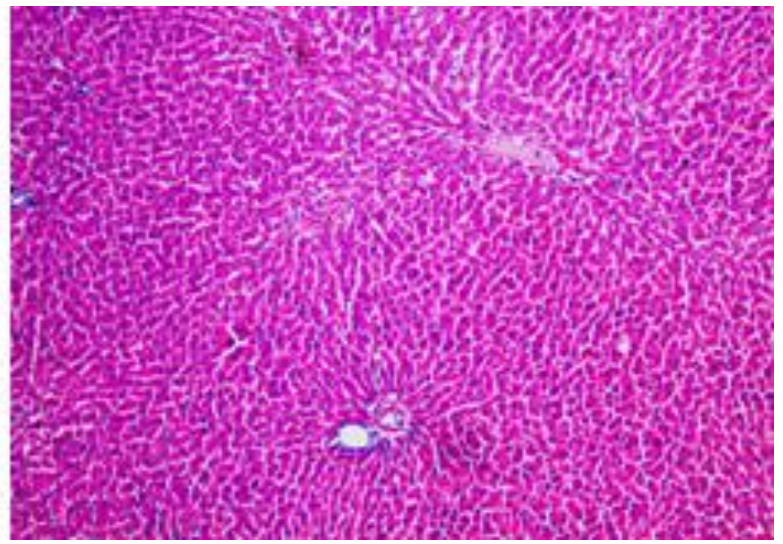

Fig. 3: Microscopically examination of liver of rats in negative control (Group I) showing the normal histological structures.

\section{Histopathological studies}

The histopathological examination of the ethanol treated groups of rate revealed degeneration and necrotic changes as compared to the administrated rate groups with alga extract which showed marked amelioration of the severity of these changes (Figures 3-8).

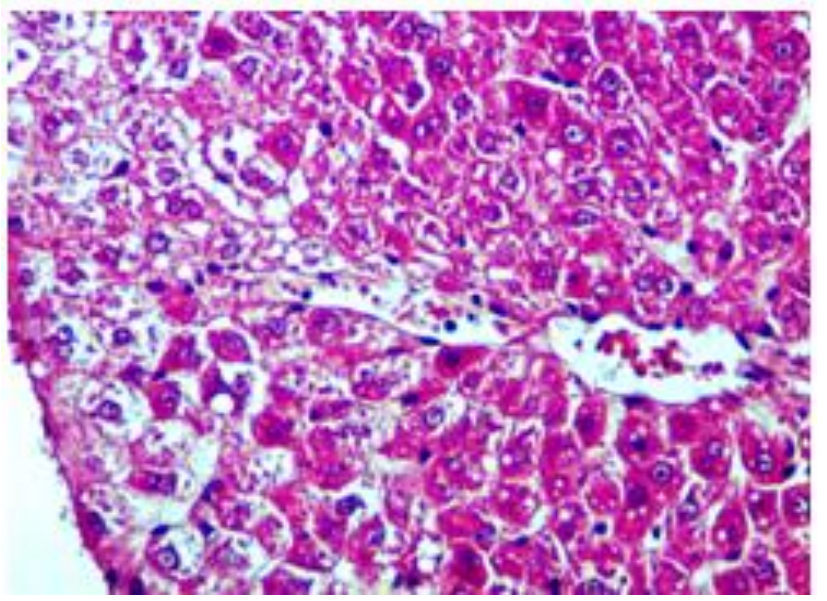

Fig. 4: Microscopically examination of liver of rats in Group II (treated with $10 \%$ ethanol) showing grade 2-fibrosis and definite increase with incomplete septa from the portal tract to central vein, those septa which don't interconnect with each other.

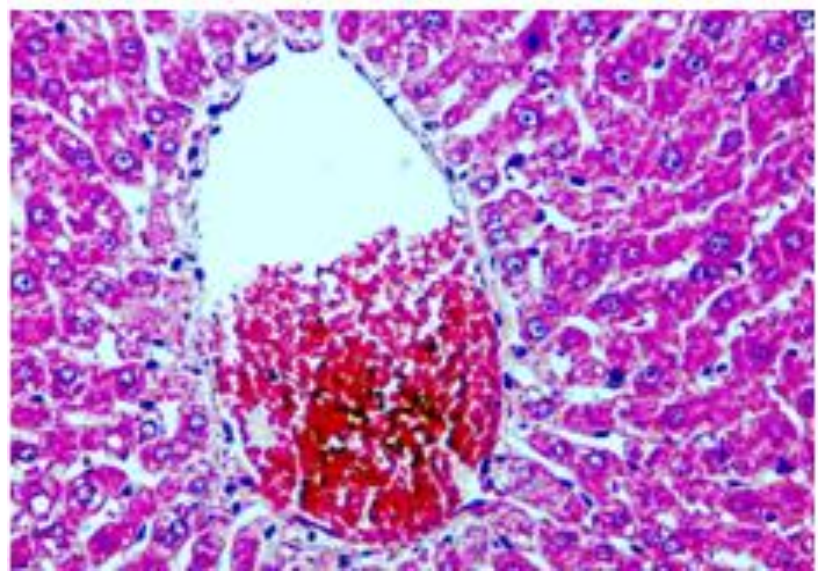

Fig. 5: Microscopically examination of liver of rats in Group III (treated with $25 \%$ ethanol) showing inflammatory leukocytic cell infiltration, hydropic degeneration and haemorrhage in the central vein.

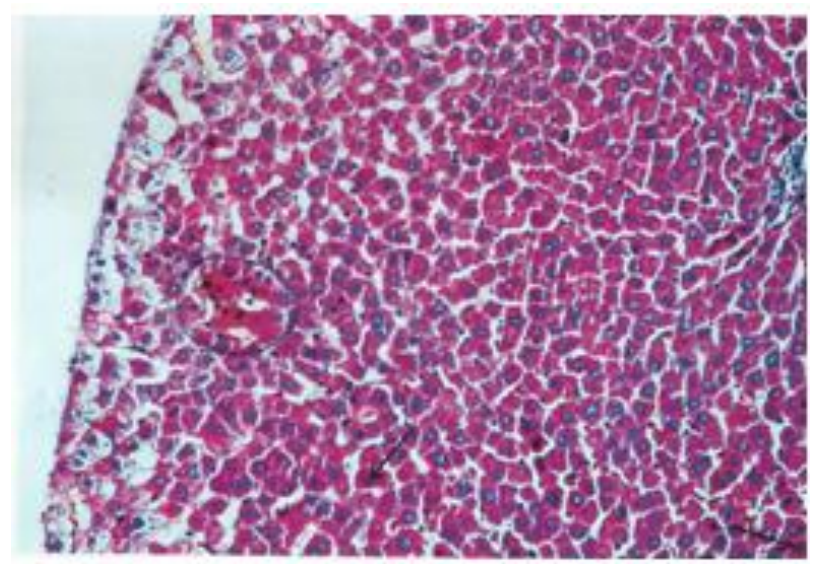

Fig. 6: Microscopically examination of liver of rats in Group IV (treated with $10 \%$ ethanol $+\mathrm{H}$. cuneiformis extract) showing congested blood vessels and few necroses. 


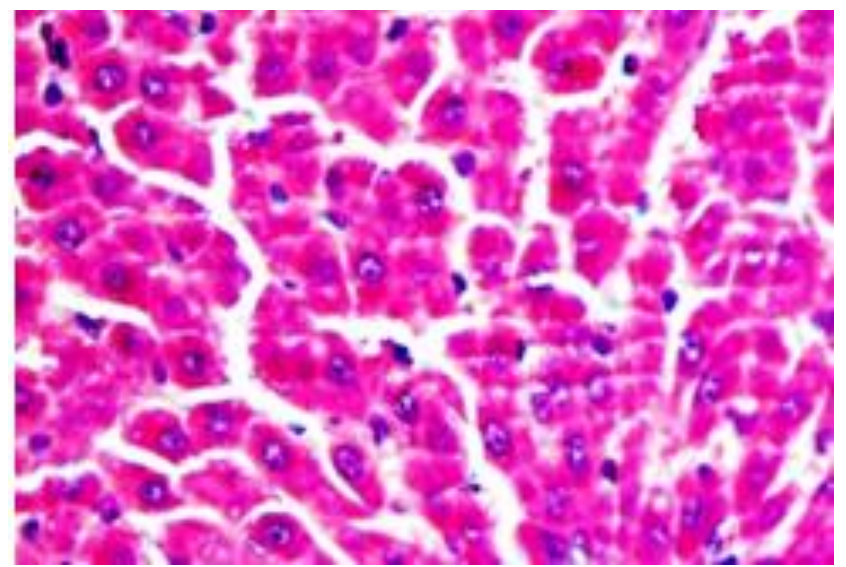

Fig. 7: Microscopically examination of liver of rats in Group V (treated with $25 \%$ ethanol $+\mathrm{H}$. cuneiformis extract) showing swelling of hepatocytes and mild degeneration. In addition, focal areas of necrosis appeared.

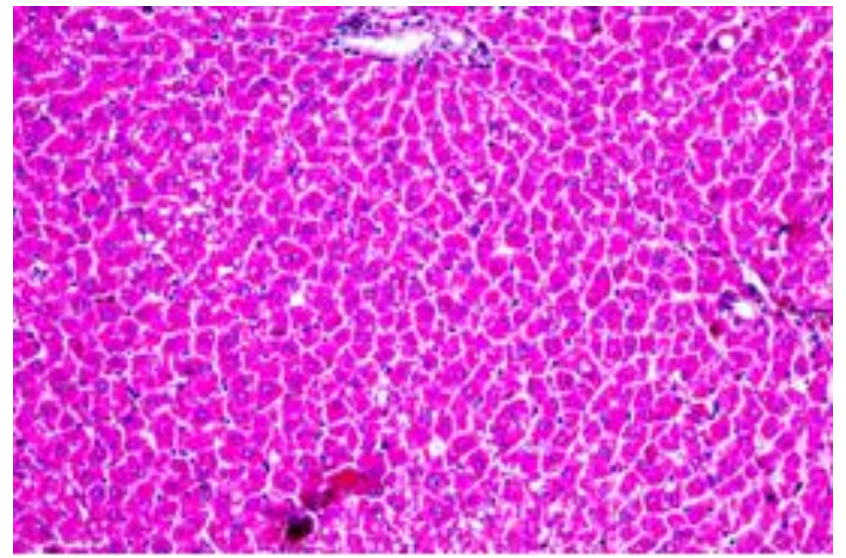

Fig. 8: Microscopically examination of liver of rats in Group VI (treated with H. cuneiformis extract) showing normal liver without collagen or fibrosis, normal liver architecture of hepatocytes since they were well arranged without any alternation at central vein. Hepatic cells were polyhedral in shape with defined cell lining in the liver tissue. The cytoplasm was well preserved with prominent nucleus and nucleolus indicating no fibrosis.

\section{CONCLUSION}

Brown alga Hormophysa cuneiformis collected from south coast of Arabian Gulf (Ad Dammam seashore), has been shown to possess a specific antimicrobial and anti-hyperlipidemic activities. These observations showed their importance as a potential source for biological active compounds. It could be concluded that extracts of $H$. cuneiformis were able to reduce all the elevated biochemical parameters and had therapeutic and preventive efficiencies in ethanol induced hepatotoxicity in rats.

\section{ACKNOWLEDGMENT}

The authors advance thanks and appreciation to the Department of Botany and Microbiology, Collage of Science, $\mathrm{KSU}$ on sponsorship to conduct research.

\section{REFERENCES}

Abdel-Raouf N., Ibraheem I.B.M., Abdel-Tawab S., and Naser Y. Antimicrobial and anti- hyperlipidemic activities of isolated Qercetin from Anabaena aequalis. Journal of Phycology 2011; 47: 955-962.
Ahmed V.U., Aliya R., Perveen S., and Samuel M. Stereoids from marine green alga Codium decortacatum. Phytochem 1993; 33:11891192.

Al-Harthi M., and El-Deek A. Effect of different dietary concentrations of brown marine algae (Sargassum dentifebium) prepared by different methods on plasma and yolk lipid profiles, yolk total carotene and lutein plus Zeaxanthin of laying hens. Italian Journal of Animal Science 2012;11: 347-353.

Ali M.S., Saleem M., Yamdagni R., and Ali M.A. Steroid and antibacterial glycosides from marine green alga Codium iyengarii Borgesen. Natural Product Letters 2002; 16: 407-413.

Aliya R., Shameel M., Usmanghani K., and Ahmad V.U. Analysis of fatty acids form Codium iyegarii (Bryopsidophyceae). Pakistan Journal Pharmaceutical Science 1991;4: 103-111.

Athukorala Y., Nam K., Jeon Y. Antiproliferative and antioxidant properties of an enzymatic hydrolysate from brown alga Ecklonia cava. Food Chem. Toxicol 2006;44:1065-1074.

Baldi F., Burra P., Plebani M., and Salvagnini M. Serum malondialdehyde and mitochondrial aspartate aminotransferase activity as markers of chronic alcohol intake and alcoholic liver disease. Italian Journal of Gastroenterology 1993;25 (8) :429-432.

Berliner J. A., and Heinecks J.W. The role of oxidized lipoproteins in atherogenesis. Free Radical Biol. Med 1996; 20: 707.

Boynes J.W. Role of oxidative stress in development of complication in diabetes. Diabetes 1991; 40: 405-411.

Cardelina I.H., Marner E.I., and Moore R.E. Seaweed dermatitis: structure of lyngbyatoxin. Science 1979; 4: 193-197.

Capasso A. 2012. Medicinal plants as antioxidant agents: Understanding Their Mechanism of action and therapeutic efficacy. 189203 ISBN: 978-81-308-0509-2.

Chakraborty K., and Lipton A.P. Guaianeses-quiterpenes from seaweed Ulva fasciata and their antibacterial properties. European Journal of Medicinal Chemistry 2010; 45: 2237-2244.

Choi J.S., Yokozawa T., and Oura H. Antihyperlipidemic effect of flavonoids from Prunus davidiana. J. Nat. Prod 1991;54: 218-224.

Collier A., Wilson R., Bradley H., Thomson J.A., and Small M. Free radical activity is type 2 diabetes. Diabetic Med 1990; 7: 27-30.

Connor W.E. N-3 fatty acids from fish oil. Panacea or nostrum? Am J Clin Nutr 2001;74: 415-416.

Devi K.P., Suganthy N., Kesika P., and Pandian S.K. Bioprotective properties of seaweed: In vitro evaluation of antioxidant activity and antimicrobial activity against food borne bacteria in relation to polyphenolic content. BMC Complementary and Alternative Medicine 2008; 8: 37-48.

Dianzani M.U. Biochemical aspects of fatty liver. In: Slatter, T.F. (ed.) Biochemical Mechanisms of Liver Injury. New York, Academic Press 1978.

Dmirel Z., Yilmaz-Koz F.F., Karabay-yavasoglu U.N., Ozdemir G., and Sukatar A. Antimicrobial and antioxidant activity of brown algae from the Aegean. Sea. J. Serb. Chem. Soc. 2009; 74: 619-28.

Duan X.J., Zhang W.W., Li X.M., and Wang B.G. Evaluation of antioxidant property of extract and fractions obtained from a red alga, Polysiphonia urceolata. Food Chem 2006; 95: 37-43.

Fki I., Bouaziz M., Sahnoun Z., and Sayadi, S. Hypocholesterolemic effects of phenolic-rich extracts of Chemlali olive cultivar in rats fed a cholesterol-rich diet. Bioorg. Med. Chem 2005; 13: 5362-5370.

Friedman R.B., Anderson R.E., Entine S.M., and Hirshberg S.B. Effects of diseases on clinical laboratory tests. Clinical Chemistry 26 (Suppl. 4), ID-476D. 1980.

Fung A., Hamid N., and Lu J. Fucoxanthin content and antioxidant properties of Undria pinnatifda. Food chemistry 2013; 136: 1055-1062.

Ganesan B., Rajesh R., Anandan R., and Dhandapani N. Biochemical studies on the protective effect of betaine on mitochondrial function in experimentally induced myocardial infarction in rats. J. Health Science 2007; 53: 671-681.

Halliwell B. The antioxidant paradox. Lancet, 2000; 355: 1179- 
Henry J.B. Clinical diagnosis and management by laboratory methods. 20th (ed.) Philadelphia, PA: W. B. Saunders Company 2001.

Horie S., Tsutsumi S., Takada Y., and Kimura J. Antibacterial quinone metabolite from the brown alga, Sargassum sagamianum. Bulletin of the Chemical Society of Japan 2008; 81: 1125-1130.

Howard C., and Hughes J.R. Anaesthesia for animals. Laboratory animals". 1981;10, 5: $40-56$.

Ibraheem I.B.M., Abdel-Raouf N., Abdel-Hameed M.S., and ElYamany K. Antimicrobial and antiviral activities against Newcastledisease virus (NDV) from marine algae isolated from Qusier and Marsa-Alam Seashore (Red Sea), Egypt. African Journal of Biotechnology 2012; 11(33): 8332-8340

John K.S., Kathiravan M.K., Somani R.S., and Shishoo C.J. The biology and chemistry of hyperlipidemia. Bioorg. Med. Chem 2005; 15: 4674-4699.

Kerr M.E., Bender C.M., Monti E.J. An introduction to oxygen free radicals. Heart and Lung 1991; 25 (3) : 200-209.

Kume H., Okazaki K., and Sasaki H. Hepatoprotective effects of whey protein on D-galactosamine-induced hepatitis and liver fibrosis in rats. Biosci Biotechnol Biochem. 2006; 70: 1281-1285.

Laurienzo P. Marine polysaccharides in pharmaceutical applications: an overview. Marine Drugs 2010; 8: 2435-2465.

Li A. H., Cheng K., Wong C., King-Wai F., Feng C., and Yue J. Evaluation of antioxidant capacity and total phenolic content of different fractions of selected microalgae. Food Chem 2007; 102: 771-776.

Li B., Lu F., Wei X., and Zhao R. Fucoidan: structure and bioactivity Molecules, 2008; 13: 1671-1695.

Lucke J. N. Euthamasia in small animals. Vet. Res 1979; 104: 316-318.

McDermid K.J., and Stuercke B. Nutritional composition of edible Hawaiian seaweeds. J. Appl. Phycol 2003; 15: 513-524.

Metodiewa D., and Koska C. Reactive oxygen species and reactive nitrogen species: relevance to cyto (neurons) toxic events and neurologic disorders. An overview, Neurotox Res 2000; 1(3): 197-233.

Murata M., and Nakazoe J. Production and use of marine algae in Japan. JARQ 2001; 35(4) : 281-2990.

Oh K.B., Lee J.H., Chung S.C., Shin J., Shin H.J., Kim H.K., and Lee H.S. Antimicrobial activities of the bromophenols from the red alga Odonthalia corymbifera and some synthetic derivatives. Bioorganic and Medicinal Chemistry Letters 2008;18: 104-108.

Patterson G.M.L., Parker D.L., and Bolis C.M. Fungal cell wall polysaccharide elicits an antifungal two metabolite (phytoalexin) in the cyanobacterium Scytonema ocellatona. J. Phycol 1994; 33: 54-60.

Prabhu N., Divya T.R., and Yamuna G. Synthesis of silver phytonanoparticles and their antibacterial efficacy. Digest Journal of Nanomaterials Biostructures 2010;5: 185-189.

Qi H., Zhao T. Zhang Q., Li Z., Zhao Z., and Xing R. Antioxidant activity of different molecular weight sulfated polysaccharides from Ulva pertusa Kjellm (Chlorophyta). Appl. Phycol 2005; 17: 527-534

Rajasulochana P., Dhamotharan R., Krishnamoorthy P., and Murugesan S. Antibacterial activity of the extracts of marine red and brown algae. Journal of American Science 2009; 5: 20-25.

Rosell K.G., and Srivastava L.M. Fatty acids as antimicrobial substances in brown algae. Hydrobiologia 1987; 151/152: 471-475.
Rota S., Mc-William, N. A., Baglin T.P., and Byrne C.D. Atherogenic lipoproteins support assembly of the prothrombinase complex and thrombin generation modulation by oxidation and vitamin E. Blood 1998; 91: 509-515.

Ruberto G., Baratta M.T., Biondi D.M., and Amico V. Antioxidant activity of extracts of the marine algal genus Cystoseira in a micellar model system. J. Applied Phycol 2001;13: 403-407.

Sandsdalen E., Haug T., and Stensvag K. The antibacterial effect of a polyhydroxylatedfucophlorethol from the marine brown alga, Fucus vesiculosus. World Journal of Microbiology and Biotechnology 2003;19: 777-782.

Santoso J., Yumiko Y., and Takeshi S. Antioxidant activity of methanol extracts from Indonesian seaweeds in an oil emulsion model. Fish Sci 2004; 70: 183-188.

Schaefer E. J., Lichtenstein A.H., Lamom-Fava S., McNamara J. R., and Ordovas J. M. Lipoproteins, nutrition, aging, and atherosclerosis. Am J Clin Nutr 1995;61:726S-740S.

Seenivasan R., Indu H., Archana G., and Geetha S. The antibacterial activity of some marine algae from south east coast of India Journal of Pharmacy Research 2010; 3: 1907-1912.

Sims J.J., Donnell M.S., Leary J.V., and Lacy G.H. Antimicrobial agents from marine algae. Antimicrobial Agents and Chemotherapy3 1975; 320-321.

Sudhahar V., Kumar S.A., Sudharsan P.T., and Varalakshmi P. Protective effect of lupeol and its ester on cardiac abnormalities in experimental hypercholesterolemia. Vasc. Pharmacol 2007; 46: 412-418.

Uma R., Sivasubramanian V., and Devaraj S. Evaluation of vitro antioxidant activities and antiproliferative activity of green microalgae, Desmococcus olivaceous and Chlorococcum humicola. J. Algal Biomass Utln 2011; 2(3): 82-93.

Vairappan C. S. Potent antibacterial activity of halogenated metabolites from Malaysian red algae, Laurencia majuscule (Rhodomelaceae Ceramiales). Biomolecular Engineering 2003; 20: 255259.

Vairappan C.S., Suzuki M., Motomuraa T., and Ichimura T. Pathogenic bacteria associated with lesions and thallus bleaching symptoms in the Japanese kelp Laminaria religiosa Miyabe (Laminariales, Phaeophyceae). Hydrobiologia 2001; 445: 183-191

Wallach J. Interpretation of diagnostic tests. 7th (ed.) Philadelphia: Lippincott Williams and Wilkins. 2000.

Yokozawa T., Cho E.J., Sasaki S., Satoh A., Okamato T., and Sei Y. The protective role of Chinese prescription kangen-karyu extract on diet-induced hypercholesterolemia in rats. Biol. Pharm. Bull 2006; 29 : 760-765.

Young I.S., and Woodside J.V. Antioxidants in health and disease. J Clin Pathol 2001;54 (3): 176-186.

\section{How to cite this article:}

Neveen Abdel-Raouf, Nouf Mohammad Al-Enazi , Ibraheem B.M. Ibraheem, Reem Mohammad Al-Harbie. Antibacterial and antihyperlipidemic activities of the brown alga Hormophysa cuneiformis from Ad Dammam Seashore. J App Pharm Sci, 2015; 5 (08): 114-125. 